\title{
Performance accountability of public agencies in the act government
}

\author{
Prof. Abd. Rahman \\ Lecturer Kopertis Region. IX Sulawesi \\ Email :abdrahman01@yahoo.com
}

ARTICLE INFO

Article history:

Received, August 25, 2017

Revised, September 10, 2017

Accepted, November 112017

Keywords:

Accountability

Government's actions

Public Bodies

\section{ABSTRACT}

Performance accountability of public bodies meaning widespread not only limited liability in law but also in the field of non-law. Special accountability law, imaged through the performance creation of the law (legal creating), as well as in the implementation of the law (legal applying) as the embodiment of government action (Bestuurhandeling). In the concept of the law of State administration and administrative law, Government action in question is the Act or acts committed by State administration in carrying out the task of Government.

Copyright @ 2017 Indonesia Prime. All rights reserved

\section{Introduction}

In the concept of the law of State administration and/or administrative law, Government action in question is the Act or acts committed by State administration in carrying out the task of Government. CF. Strong, interprets the State administration is any organ or body that has the power of the public. Whereas the task of the Government that tasks not included in the task of creating the rules and duties of the judge (the theory of the time). Thus, the Government action in question not just done by the Agency of the public whose name the Executive, but also carried out by the legislative and the judicial. In theory the Trias politica from Monstesquieu, the country was then given the function of the formation of laws (legislation), the function of implementing legislation (Government) and the function of the judge (Justice). These functions then divided into three State agencies runs out, that is, legislative, Executive, and judicial.

Based on the principle of legality as the embodiment of the principles of State law, then the execution of the functions and the powers of Government should be put on the rule of law, i.e.: - any powers in the State should base on the law; -available the implementation of the and legal protection of the use of the powers of the Government; -the principle of the responsibility to sue (liability) of any use of the authority.

In administrative law, the implementation of the principle of the legality of it became more important in the relationship between the Government of the people. On the one hand provide legal protection for the people who ruled, on the other hand, limits the use of the powers of Government. If then there a diversion and/or abuse of authority by officials of The State then open the possibility do legal complain as a manifestation of the accountability law (legal accountability). Which a form of legal liability so that every action of the State Administrative officials or Government action can account for the functional supervisory bodies or agencies of the legislative, and the judicial bodies. The latter called control judicial against government actions whether through judicial or public Administrative Justice to the Supreme Court of the country as 
Cassation level courts. Under article $24 \mathrm{C}$ of the Constitution of the year 1945, NRI judiciary incremented one more that is the Constitutional Court, the special handle attempt to create problems.

Based on the above arguments, then the compiled pattern work below as the focus of our discussion is the issue/:

1. The territorial agency performance accountability;

2. Performance accountability Executive Board;

3. Judicial agency performance accountability.

\section{Performance Accountability Legislation}

Based on the Constitution of 1945, the Year NRI legislative represented to the parliament as a body of common law (article 20). Although there is a DPD, these bodies only positioned as an auxiliary organ of the support functions of the house legislation. Therefore, with the presence of new representative institutions as DPD in the system's attempt to Indonesia, does not mean that Indonesia has embraced a Bicameral system, but it is still a unicameral system. Two representative systems (bicameral system) not seen in the existence of the two organs as representative institutions, but do they have the Authority organs of the formation of laws. The presence of a country that is not functional, the existence and/or the performance of the is questionable because it does not have a product state administration that is directly beneficial to the interests of the community, the nation, and the State. Even his presence only as political assessor thus burdening the State budget to finance the State's inefficiency occurs. Therefore, the Agency should be evaluated through a revision of the Constitution to give the same strong role with the HOUSE towards the creation of a strong bicameral system is effective. If this agency should not just have liquidated and reaffirmed the constitutional basis of our representative system that was a unicameral system without DPD. Even the presence of any questionable MPR because in addition to no longer have the authority routinely continuously, also lack interest representation. If the HOUSE of representatives representing the political interests of the community as a whole (political representation), then the house of representatives to represent the interests of the region (Regional representation). If the MPR interests who represented? If it's just to run the three MPR authority under article 3 of the constitution of the year 1945, then the NRI can only be carried out by the House and DPD in the joint session of the forum (joint session) that does not make it as an independent institution such as the MPR now These.

Performance accountability areas of legislation the house marked with national legislation and the establishment of the Act. Whether laws that formed in a single year budget amount complies with the national legislation programmed as this relates to performance measures and budget state budget burden.

In the formation of the Act, the performance of the parliament is very related to the enforceability of the law. J.J.H. Bruggink, divide the enforceability of the law into three sections, namely the enforceability of factual, normative, enforceability and evaluative.

Enforceability of factual relating to the effectiveness of the methods of compliance due to legal residents on the rule of law, because the law intervenes and empiric in favor of their interests. Enforceability of normative (formal enforceability) is if the method that is part of a system of the specific legal method in which mutual pointing one against the other. While the enforceability of evaluative, is the legal enforceability of the methods because of its content is viewed. Or the method of the law by a person or a Community accepted. According to the author of an act not through the process of its formation as aforesaid, then based on the thought that Act least Bruggink has only formal or normative method of enforceability of the law but has no enforceability of factual and enforceability of evaluative. Karel Frequently in his book dear reader the rules stated only Sinaga has value semantic, i.e., legally valid indeed but merely to give form or exercise the political power for the benefit of the holders of power.

Good legislation is legislation which qualifies this enforceability so effective and acceptable to 
the community. In Act No. 12 the Year 2011 about the formation of legislation, there is the principle of the formation of legislation which describes the enforceability of terms above.

The court often cancels much of this latter Act through a process of judicial a review. Saldi Isra mention since the year 2003-2009 there is approximately 247 of the ACT presented to the constitutional court to tested the validity of the enactment, 58 of which granted. This is due, among others, the formulation of normative formulae should be charge material ACT colored by political expediency is practically making the ACT of losing the spirit of enforceability. Based on an ACT in the exercise of his duties, MD3, the house of representatives through the Committee for the designer of the Act can do:

1. Work meetings with the Government, a local government district/city, provincial;

2. Public Hearing (RDPU);

3. Hold the working visits;

4. Hold a comparative study;

Even on other parts, said that against the aspirations of the community, members of Parliament convened, absorb, hold and follow up. This provision of its nature is imperative and not a facultative, since it is related to the principle of openness in the formation of the ACT as set forth in Act No. 12 the Year 2011 that is, in the process of formation of the regulations starting from the planning, preparation, the preparation of, and discussion, is transparent and open. Thus, all walks of life to have a chance of existence to provide input into the process of the formation of legislation. The formation of the Act without the participation of the community is a model democracy piracy elite. Danial Sparringga calls it democracy lost their lives (zombies) that there is a practice of no value, but there was a process but lost his spirit. There is a body but did not have the heart (undead). That's the case, our democratic system produces a zombie because there is a body, but no lives. Analogous in the thoughts above, deviations against the mechanism and neglect against the participation of the public in the process of formation of the Act will make the Act was the loss of the spirit with a value of normatively, except it only has value semantic.
More than that would also affect the strength of the validity period.

\section{Performance Accountability Executive Board}

In a presidential system of Government, accountability for performance controlled through the leadership of the head of Government is called the President. The President is not accountable to Parliament but is responsible according to the Constitution. Based on the constitution of the 1945 Year NRI, new President of the liability occurred when the President of the criminal law, in the form of treason against the State, corruption, bribery, other heavy criminal acts, or conduct reprehensible, and/or the President and/ or the Vice President no longer qualify as the President and/or Vice President. In contrast to the presidential accountability based on the 1945 Constitution (amendments to pre), in which the President can be dismissed offhand by the MPR merely because the President did the breach of the GBHN. The dismissal of the President right now is two mechanisms, i.e., the mechanism of political and legal mechanisms. Political mechanism in the form of the opinion of the house of representatives that the President do violations of the law as the provisions of article 7B subsection (1), while the political mechanism if the constitutional court through the nine judge constitution decided that the house of representatives agreed with the opinion in up, and then returned to the house of representatives and continued to the mpr after the internal mechanism through the decision of the house of representatives. The crucial thing that needs assessment is can the MPR decided on the dismissal of the President are the same as the desired House and MK?

This question deliberately asked questions because of the number of members of Parliament (560 members) fewer than the number of members of the assembly, where there is the addition of the 132 members of the DPD and so the total number of the MPR members as much as 692 members. The amount of this very influential voice against the majority of the to dismiss the President or the Vice-President if the DPD does not agree with the House of 
representatives and then merged with the number of votes of representatives who not agree with the majority of the parliament to dismiss the president, then could just woke up a new conspiracy not to dismiss the president.

The mechanism of this model is very potential result in two things, namely, making the ruling of the constitutional court does not have the power of executorial, and may give rise to political instability which affect economic jolts and disruption of security.

Therefore, this constitutional provision should then be evaluated for revised in two alternatives, namely, first, the political mechanism in the House and the mechanism of the law in the Constitutional Court are retained, but the need for an additional clause to get certainty the law stops so that the ruling of the constitutional court is the verdict is final and binding and has the force of executorial. the second alternative if the $\mathrm{mpr}$ is still required then ruling mpr nature declarator to strengthen the legal position has been decided by the constitutional court (constitutive).

\section{Judicial Agency Performance Accountability}

The Cinstitution 1945 NRI determine as the perpetrator of the powers of the judiciary, not just carried out by MA and other judicial institutions but also done by the Constitutional Court. Two things that need to scrutinize is the first, about the recruitment of Judges and surveillance behavior of judges, and second, the accountability of judges of the constitutional court.

\subsection{Recruitment of Judges and surveillance behavior of Judges}

\section{A. Recruitment of Judges.}

Political commitment has become a constitutionally enshrined into the task of the judicial Commission (KY), but KY is in a State of institutional system is categorized as an Auxiliary organ of the state, i.e., as an organ of support against the main state organs (the house of representatives ) but does not have the authority the KY. Towards the creation of a Chief Justice who is professional, and free from the influence of any power, then it should be given a role that KY specify so that the mechanism of appointment shortened without any political influence House and ends at KY's level. Except that any supposed KY membership recruitment more tightened with a public test mechanism by an adhoc Institute a credible and accountable.

\section{B. Supervision of The Behavior of Judges}

Authority of KY in the same field his position with that of Chief Justice recruitment agencies support because the work of supervision delivered to The Supreme Court Of. Is the question can the Supreme Court Of finalty gave the judges themselves? Is it not the same as the words of Joshua in his ads "the Orange eats oranges?". Therefore, it is in this field, KY must be given the task of determining the final project or independently to provide coaching in two things, namely, coaching for the judges awarding achievers in the form of a reword and against rogue judges given punishment by clear rules. To empower there is no other way except there is a revision of the constitution against NRI Year 1945.

\subsection{Accountability of Judges of Constitutional Court}

Compared to the MA verdict is still very conventional, then the Constitutional Court has shown a positive performance and many an award being progressive. If MA still resting on the justice procedural, then the court in an award already reflects the principle of substantive justice. The application of substantive justice is already by article 24 paragraph (1) of the constitution of the 1945 Year NRI, namely to organize the judiciary to enforce the law and justice. The judge's ruling means the consideration of not only the formal rules rely on the (written) who formulated rigorously (judge as trumpeting the Act) but should also based on the rule of law is not written. The application of the principle of substantive justice reflected through 
the ruling of the constitutional court that is conditionally constitutional (e.g. application of chapter 160 of the criminal code conditional, the use of id card passport as identity selector \&). Conditionally Unconstitutional (contrary to the Constitution conditional), e.g., the convicted person can become parliamentary candidates and prospective $\mathrm{KDH}$., and the verdict of, such as the repeated voting and counting, head of KPK in the case of Bibit Samad Rianto \& Chandra $\mathrm{m}$. Hamzah, i.e. new can dismissed after a court decision that has the force of law remain.

\section{Conclusion}

In a presidential system of Government, accountability for performance is controlled through the leadership of the head of Government is called the President. The President is not accountable to Parliament but is responsible according to the Constitution. Based on the Constitution of the 1945 NRI, new President of the liability occurred when the President of the criminal law, in the form of treason against the State, corruption, bribery, other heavy criminal acts, or conduct reprehensible, and/or the President and/ or the Vice President no longer qualify as the President and/or Vice President. In contrast to the presidential accountability based on the 1945 Constitution (amendments to pre), in which the President can be dismissed offhand by the MPR merely because the President did the breach of the GBHN

Became the pride of MK's performance but need to get constitutional guarantees so they can be measured exactly, including firmness settings related to the expansion of the authority of the court. In article $24 \mathrm{C}$ of the Constitution 1945 Year NRI authorizes the court determined limitative in IE is limited to four the authority and a single liability, but now plus a new election authority KDH \& KDH Deputy categorized as election regime so that disputes the election results of the head region and Deputy head the area became the competence of the court and no longer be a competence of MA as regulated in the law No. 32 of the year 2004. To prevent the authorities of the new MK memorable unconstitutional, then the necessary revision of some provisions of the Constitution of 1945 for
Year NRI synchronized with the authority, namely Article 22E and article 24C, so that the court can also be granted authority other based on ACT like other authorities given to MA as referred to in article $24 \mathrm{~A}$ subsection (1) that "the other has the authority given by law".

\section{References}

[1] Abd. Rahman, Disertasi, Kedudukan dan Kewenangan DPD dalam Sistem Perwakilan Indonesia, Program Pascasarjana UNAIR, Surabaya, tahun 2006

[2] Arif Sidarta, refleksi tentang Hukum, Citra Aditya Bhakti, Bandung, 1996.

[3] Budiman NPD Sinaga, Hukum dan Konstitusi, penerbit Kurnia Kalam Semesta, Yogyakarta, 2005.

[4] Jimly asshiddiqie, Perkembangan dan Konsolidasi Lembaga-Lembaga Negara pasca Reformasi, penerbit Sejend dan Kepaniteraan MK_RI, Jakarta, 2006.

[5] Saldi Isra, Pergeseran Fungsi legislasi, penerbit Rajawali Pera, Jakarta.

[6] UUD NRI Tahun 1945.

[7] UU No. 12 Tahun 2011 Tentang Pembentukan Peraturan Perundang-undangan RI. 